\title{
Effect of water content on the germination characteristics of Trichosanthes cucumerina, Momocardia charantia and Abelmoschus esculentus seeds
}

\author{
Nirosha Razeek, Thananthika Sittampalam, Ranganathan Kapilan* \\ Department of Botany, University of Jaffna, Jaffna, Srilanka.
}

\begin{tabular}{l}
\hline ARTICLE INFO \\
\hline Article history: \\
Received on: $19 / 03 / 2016$ \\
Revised on: $02 / 06 / 2016$ \\
Accepted on: $30 / 08 / 2016$ \\
Available online: $23 / 10 / 2016$ \\
\hline Key words: \\
Momocardia charantia, \\
Trichosanthes cucumerina, \\
Abelmoschus esculentus, \\
water content, Germination \\
Index.
\end{tabular}
Index.

\begin{abstract}
The study was aimed to determine the effect of water content on seed germination and early seedling growth of Momocardia charantia, Trichosanthes cucumerina and Abelmoschus esculentus seeds. Each set of triplicate test tubes containing ten seeds of each Momocardia charantia, Trichosanthes cucumerina and Abelmoschus esculentus, were filled with sterile water at different water content and allowed to germinate in room temperature for seven days. Parameters measured were the percentage of germination, germination index, mean time to germination and the length of germ tube. The highest germination characteristics were observed at low and moderate water contents in all three types of plant seeds examined. The optimum germination responses were expressed by the seeds of Momocardia charantia and Trichosanthes cucumerina at $23.5 \mathrm{Kgm}^{-1} \mathrm{~s}^{-2}$ and Abelmoschus esculentus at $47.0 \mathrm{Kgm}^{-1} \mathrm{~s}^{-2}$. Moisture availability imposed severe limitations on the seed germination of the selected plant species. The seeds of Trichosanthes cucumerina, Momocardia charantia and Abelmoschus esculentus showed different range of water content tolerance for optimum germination.
\end{abstract}

\section{INTRODUCTION}

In nature, life cycle of plants continues to keep the plants alive and to maintain the life continuity [28]. Seed germination is a process in which a seed awakens from dormancy and start to sprout [7]. Germination therefore refers to sprouting of a seed or resumption of plant growth from seed. Germination of seed affects by several environmental factors such as temperature, salinity, light, nutrients and water content. The optimum temperature, light, and $\mathrm{pH}$ conditions differ considerably depending on the species $[10,35]$. Plants require different components at different rate for the successful germination of the seeds [32]. Cellular metabolism of the germinating seeds mainly depends on the amount of water uptake by the seed [36]. Mature seeds are generally dry and therefore can absorb a significant amount of water, relative to the dry weight of the seed, before the cellular metabolism and growth can resume [29]. Amount of water to be absorbed into the seeds for germination depends on

\footnotetext{
* Corresponding Author

Ranganathan Kapilan

Email: ranganat@ ualberta.ca
}

anatomical and physiological nature of the plant species. Some species require sparingly, other needs little; others need large amount of water [39]. The uptake of water or moisture in seeds is called imbibition that leads to the swelling and the breaking of the seed coat [30]. When the seed imbibes water, hydrolytic enzymes will get activated and start to breakdown the stored food resources and convert them to metabolically useful chemicals that can give energy to the seedling for emergence. Generally, basic steps involved in uptake of water into seeds are similar as uptake of moisture [30]. Trichosanthes cucumerina, Momocardia charantia, Abelmoschus esculentus are the nature's gift vegetables for human consumption. These plants are cultivated widely in tropical, subtropical and warm temperate regions around the world. Trichosanthes cucumerina is widely used as an ingredient for curry and sambol which served with rice. Momocardia charantia has diverse medicinal values that are stochmatic, laxative, anthelmintic agent, treating skin diseases, ulcer, diabetes, and rheumatism. Abelmoschus esculentus is valued for its edible green seed pods. These plants are cultivated in a wide range of climatic and geographic locations of the Island of Sri Lanka as economically important vegetables $[29,37]$. Sri Lanka is located in the tropical region, where the climatic conditions facilitate the cultivation of diverse crop varieties, which are of greater economical importance. 
Since these economically important plants are restricted mainly to the tropical and temperate regions, the germination of seeds and emergence of seedlings would definitely affected by the amount of water available in the soil for the seed germination. Large amount of water (flooding) will inhibit the seed germination and kill the seeds and emerging seedlings due to lack of air for respiration. Factors like low root temperature, osmotic stress and drought (water stress condition created by external factors) also limit the availability of water for germination of plants. Therefore it was decided to test the germination index of these selected plant seeds by providing a range of moderate amount of water for germination.

As a measure of water availability, water content that could be easily changed and measured, was used. There have been no studies conducted to compare the differences in the germination potential or germination index of the seeds and the growth rates of the seedlings of Trichosanthes cucumerina, Momocardia charantia and Abelmoschus esculentus plant in different water content values.

Therefore this study was focused on determining the effect of water content on seed germination and early growth of Trichosanthes cucumerina, Momocardia charantia and Abelmoschus esculentus.

\section{MATERIALS AND METHODS}

\subsection{Source of seeds}

The seeds of Trichosanthes cucumerina, Momocardia charantia and Abelmoschus esculentus were collected from Thirunelvely agricultural farm school of Northern province of Sri Lanka and used for this experiment.

\subsection{Effect of water content on germination}

A set of three sterile petridishes were taken and they were moistured with sterile water. In each tube, ten seeds of Trichosanthes cucumerina, Momocardia charantia and Abelmoschus esculentus were placed separately (not mixed each other) in random manner. After maintaining $23.5 \mathrm{Kgm}^{-1} \mathrm{~s}^{-2}$ water content for an hour, the petridishes were kept at a water bath set at $35^{\circ} \mathrm{C}$, under dark warm condition that is favorable for natural seed germination, for 7 days for natural seed germination. Similar experiment was repeated with 47.0, 70.5, 94.0 and 117.5 $\mathrm{Kgm}^{-1} \mathrm{~s}^{-2}$ of water content values. Respective water content values were maintained in all the experimental units. The growth measurements of germ tube changes were recorded initially. The seeds were carefully observed daily and the number of seeds germinated, the length of germ tubes and the rate of germination and other germination properties were measured. Triplicates were made for each plant type.

\subsection{Determination of water content}

Water potential is a measure of the potential energy in water (at atmospheric pressure and ambient temperature). It is denoted by the Greek letter $\psi$ (psi) and is expressed in units of pressure (in the form of energy) called megapascals (MPa). The water potential of pure water is designated a value of zero $\left(\Psi_{\mathrm{w}}{ }^{\text {pure }}\right.$ ${ }^{\mathrm{H} 2 \mathrm{O}}$ ). Water potential values for the water in a plant root, stem, or leaf are, therefore, expressed in relation to $\Psi_{\mathrm{w}}{ }^{\text {pure }}{ }^{\mathrm{H} 2 \mathrm{O}}$. The water potential in plant solutions is determined by multiple factors such as solute concentration, pressure, gravity and temperature. Water potential can be calculated by the following equation:

$$
\Psi_{\text {system }}=\Psi_{\text {total }}=\Psi_{\mathrm{s}}+\Psi_{\mathrm{p}}+\Psi_{\mathrm{g}}+\Psi_{\mathrm{m}}
$$

Where $\Psi_{\mathrm{s}}=$ solute potential, $\Psi_{\mathrm{p}}$, = pressure potential, $\Psi_{\mathrm{g}}$, = gravity potential, $\Psi_{\mathrm{m}}=$ matric potential. As the individual components change, they raise or lower the total water potential of a system. When this happens, water moves to equilibrate, moving from the compartment with a higher water potential to the compartment with a lower water potential. This brings the difference in water potential between the two systems $(\Delta)$ back to zero [3].

\subsection{Determination of germination mean time and germination indices}

$$
G M T=\frac{\Sigma(\mathrm{nT})}{\sum \mathrm{n}}
$$

n- Number of seeds newly germinated at a time T, T- Hour from the beginning of the germination test, $\Sigma \mathrm{n}$ - Final germination [36]. All the other germination characteristics were measured using the equipments and parameters used in the previous studies $[36,20]$.

\subsection{Statistical analysis}

Statistical analyses was performed using $\mathrm{R} \quad 2.15 .3$ statistical software at $\alpha=0.05$ confidence level. Box plots were used for identifying outliers from the data set that were removed before the statistical analysis. When necessary to meet the assumptions of normality and homogeneity of variance, the data were transformed, either by $\log$ transformation or square root transformation. The data were analyzed using ANOVA. Tukey's multiple comparison tests was used to determine significant differences at $\mathrm{p} \leq 0.05$ [31].

\section{RESULTS AND DISCUSSION}

Trichosanthes cucumerina has the capacity of growing in a wide range of moisture content. The germination percentage of Trichosanthes cucumerina, after five days of germination was very low, at higher moisture content. Germination percentage decreased with the increasing water content values. Highest germination percentage was observed at $23.5 \mathrm{Kgm}^{-1} \mathrm{~s}^{-2}$ and this is considered as optimum.

The length of the germ tube also showed similar trend as the germination percentage (Figure 1). 


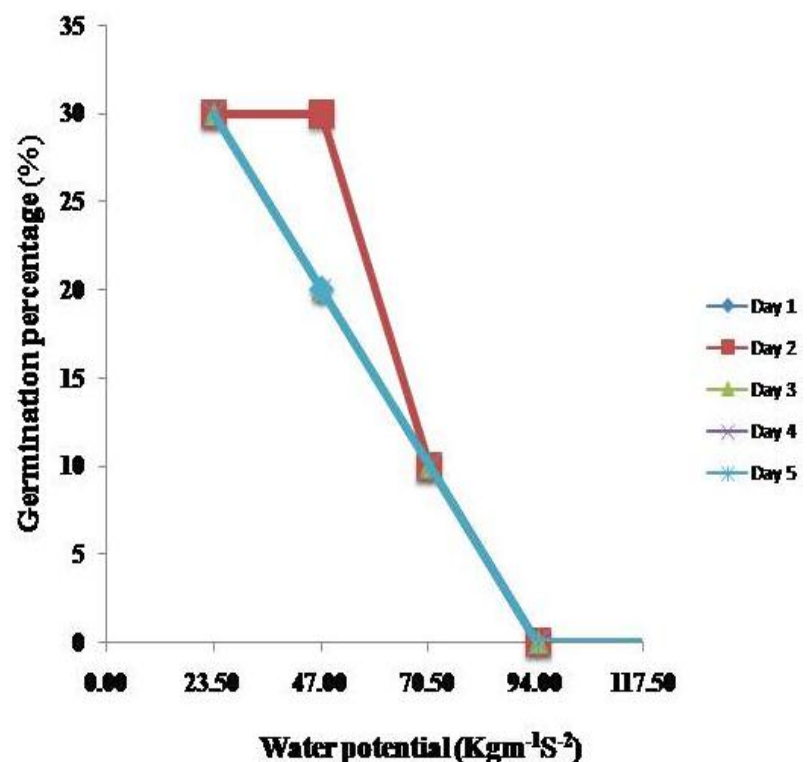

Fig. 1: Percentage of germination of seeds of Trichosanthes cucumerina at different water contents.

Germination Mean Time (GMT) of Trichosanthes cucumerina after seven days of germination period, was stable at low water content values. At $23.5 \mathrm{Kgm}^{-1} \mathrm{~s}^{-2}$, mean germination time of snake gourd was significantly higher than the other water content values tested. When the water content was very high $\left(117.5 \mathrm{Kgm}^{-1} \mathrm{~s}^{-2}\right.$, again the GMT declined (Figure 2).

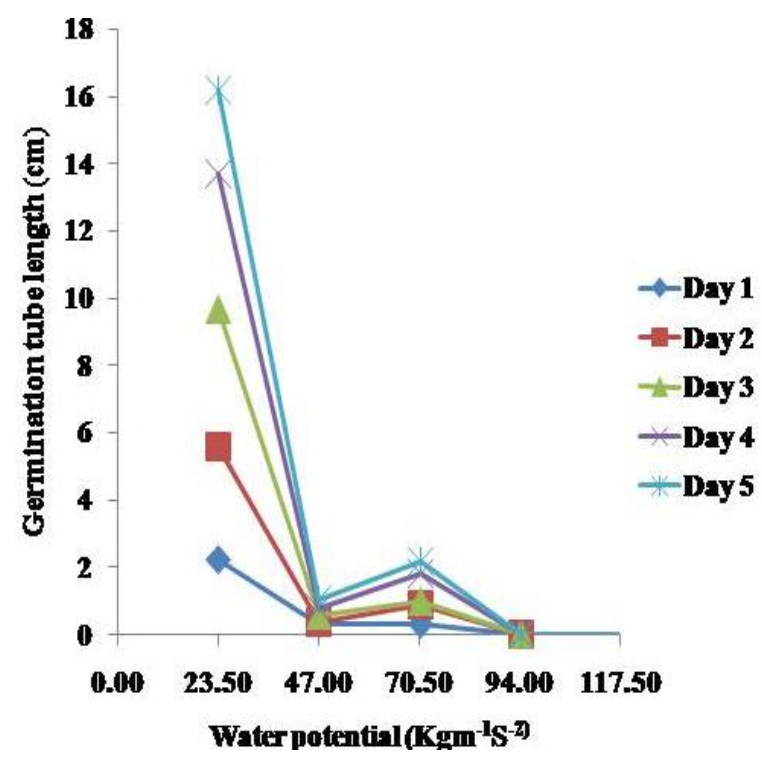

Fig. 2: Length of germ tube of the seeds of Trichosanthes cucumerina at different water contents.

Germination index of snake gourd was also showed the similar trend, after 7 days of germination (Figure 3). Seeds of snake gourd showed differences in responses of seed germination under different moisture level (Figure 4).

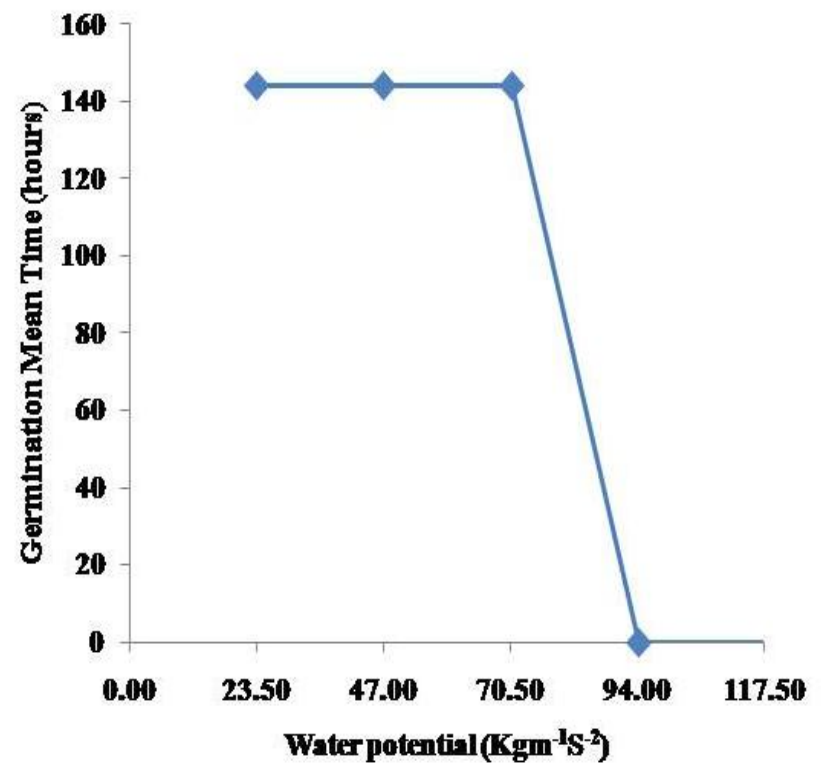

Fig. 3: Germination mean time of the seeds of Trichosanthes cucumerina at different water contents.

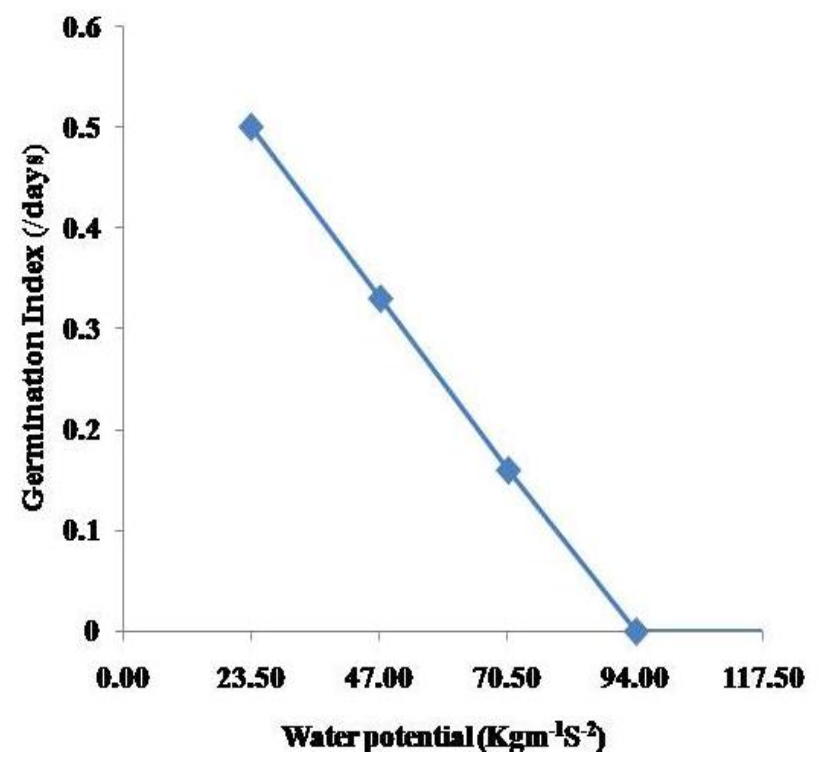

Fig. 4: Germination Index of the seeds of Trichosanthes cucumerina at different water contents.

Momocardia charantia has the capacity of growing in a narrow range of water content. The germination percentage of bitter guard, after five days of germination was very low, 94.0 $\mathrm{Kgm}^{-1} \mathrm{~s}^{-2}$ (Figure 5). 


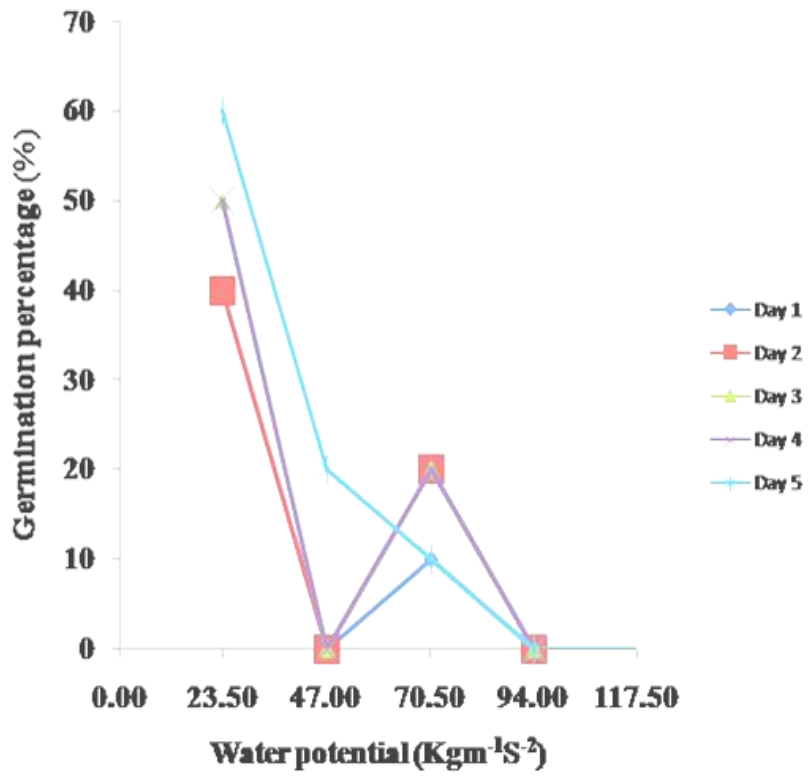

Fig. 5: Percentage of germination of the seeds of Momocardia charantia at different water contents.

Germination percentage increased with the water content from 0.0 up to $23.5 \mathrm{Kgm}^{-1} \mathrm{~s}^{-2}$, and beyond this water content, the germination percentage started to decline. Highest germination percentage was observed at $23.5 \mathrm{Kg}^{-1} \mathrm{~s}^{-2}$ and this is considered as optimum. The germination percentage at $94.0 \mathrm{Kgm}^{-1} \mathrm{~s}^{-2} \mathrm{ml}$, was significantly lower than that of $23.5 \mathrm{Kgm}^{-1} \mathrm{~s}^{-2}(\mathrm{p}=0.05)$ after 5 days of germination. The length of the germ tube also showed similar trend as the germination percentage (Figure 6).

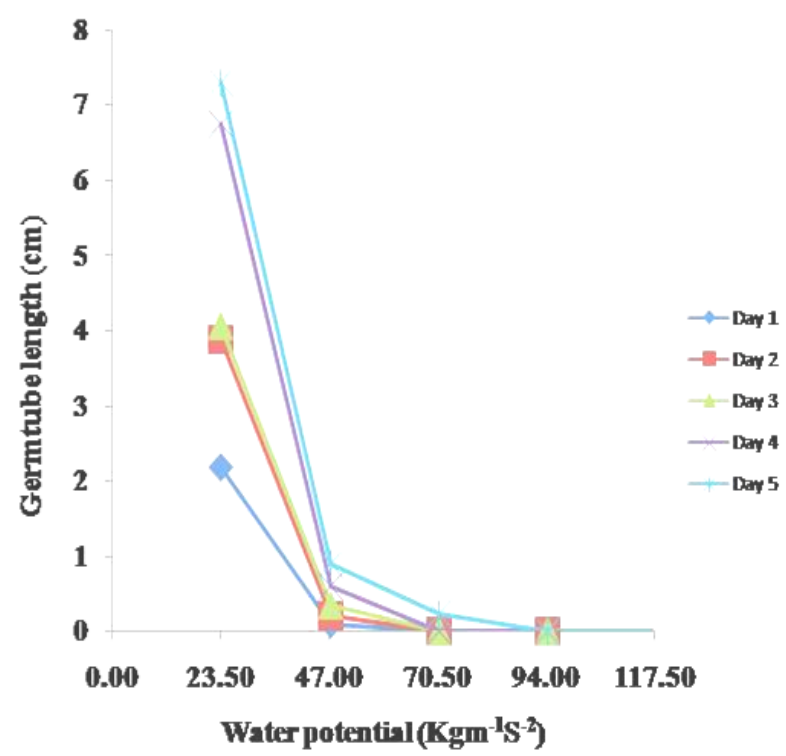

Fig. 6: Length of germ tube of the seeds of Momocardia charantia at different water contents

It was significantly lower at highest water content $\left(117.5 \mathrm{Kgm}^{-1} \mathrm{~s}\right.$ $\left.{ }^{2}\right)$, than that less water content $\left(23.5 \mathrm{Kgm}^{-1} \mathrm{~s}^{-2}\right)$. Mean germination time (MGT) of Momocardia charantia after seven days of germination period, was stable at low water content. At 23.05 $\mathrm{Kgm}^{-1} \mathrm{~s}^{-2}$, mean germination time of bitter gourd was significantly higher than the other water contents. When the water content was increased to117.5 $\mathrm{Kgm}^{-1} \mathrm{~s}^{-2}$, again the MGT declined (Figure 7).

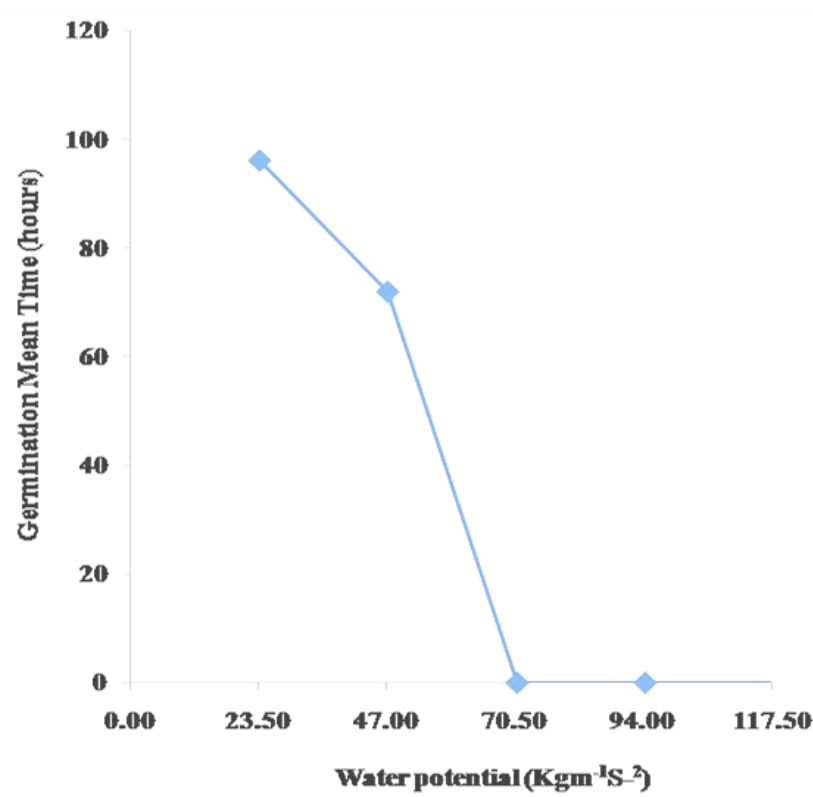

Fig. 7: Germination mean time of the seeds of Momocardia charantia at different water contents.

Germination index of bitter gourd was also showed the similar trend, after 7 days of germination (Figure 8). Seeds of bitter gourd showed differences in responses of seed germination under different moisture treatment.

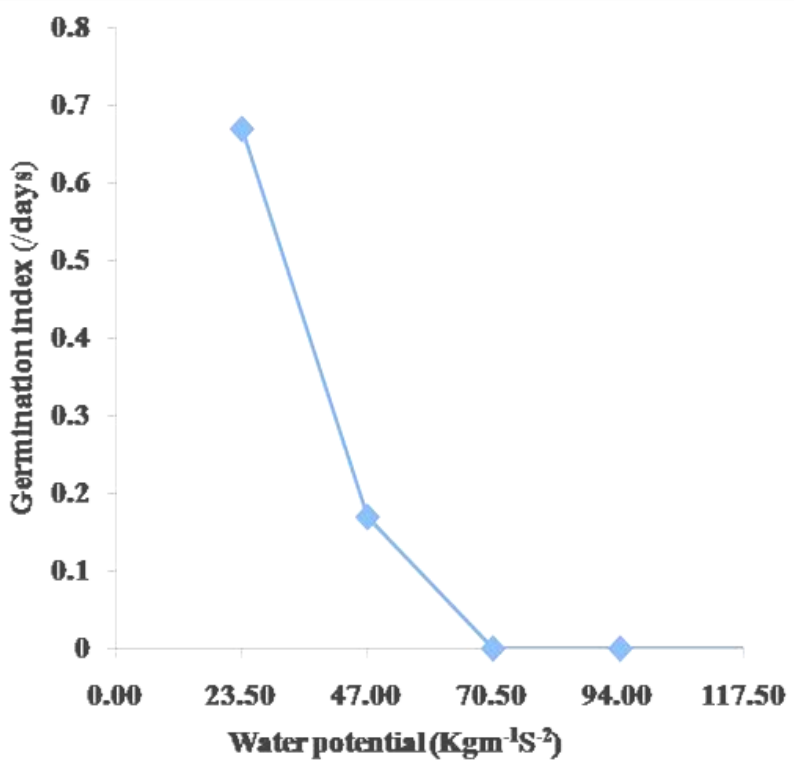

Fig. 8: Germination index of the seeds of Momocardia charantia at different water contents. 
Abelmoschus esculentus has the capacity of growing in a wide range of water content compared to Trichosanthes cucumerina and Momocardia charantia. The germination percentage of okra, after five days of germination was very low, at high water content (Figure 9).

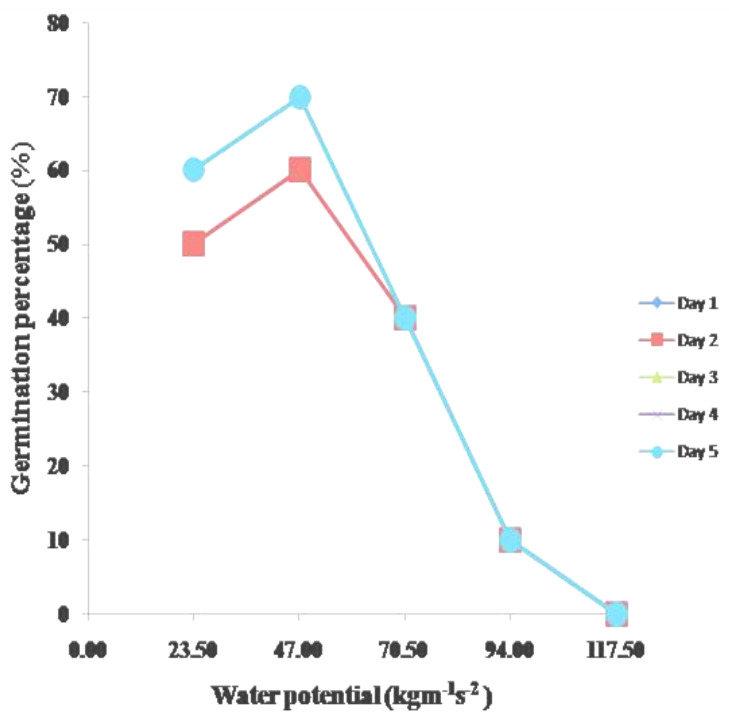

Fig. 9: Percentage of germination of the seeds of Abelmoschus esculentus at different water contents.

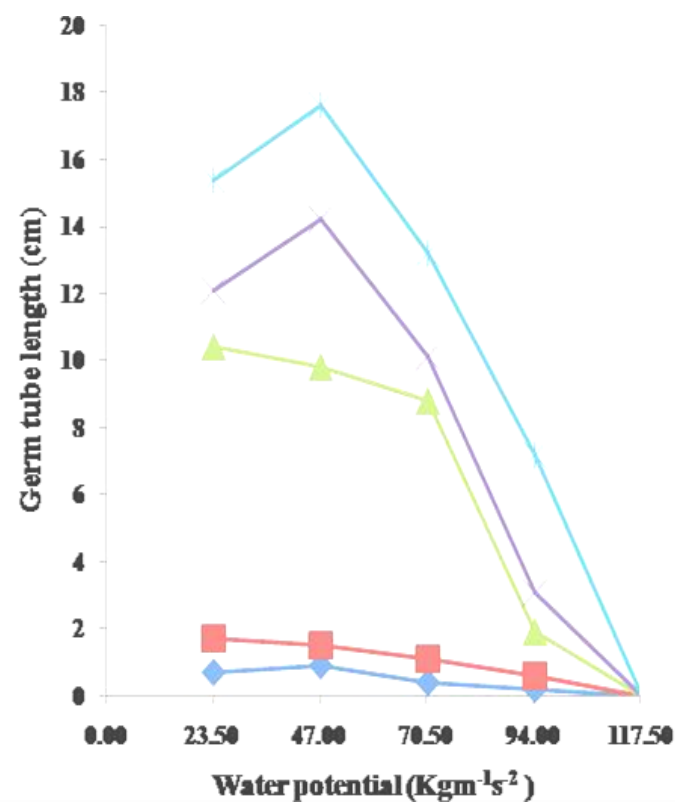

Fig. 10: Length of germ tube of the seeds of Abelmoschus esculentus at different water contents

Highest germination percentage was observed at 47.0 $\mathrm{Kgm}-1 \mathrm{~s}-2$ and this is considered as optimum. The germination percentage at $117.0 \mathrm{Kgm}^{-1} \mathrm{~s}^{-2}$, was significantly lower than other water content levels $(\mathrm{p}=0.05)$ after 5 days of germination. The length of the germ tube also showed similar trend as the germination percentage (Figure 10). Mean germination time (MGT) of Abelmoschus esculentus after seven days of germination period, was stable at low water content. At $94.0 \mathrm{Kgm}^{-1} \mathrm{~s}^{-2}$, Germination Mean Time of okra was significantly higher than the other water contents. When the water content was increased to1 $17.5 \mathrm{kgm}^{-1} \mathrm{~s}^{-2}$, again the MGT declined (Figure 11).

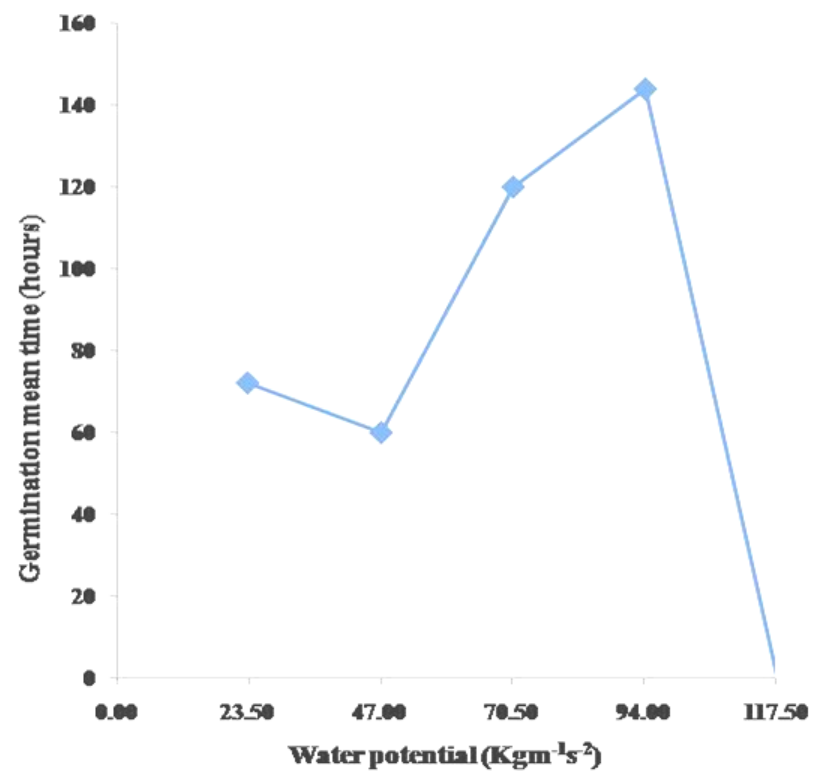

Fig. 11: Germination mean time of the seeds of Abelmoschus esculentus at different water contents.

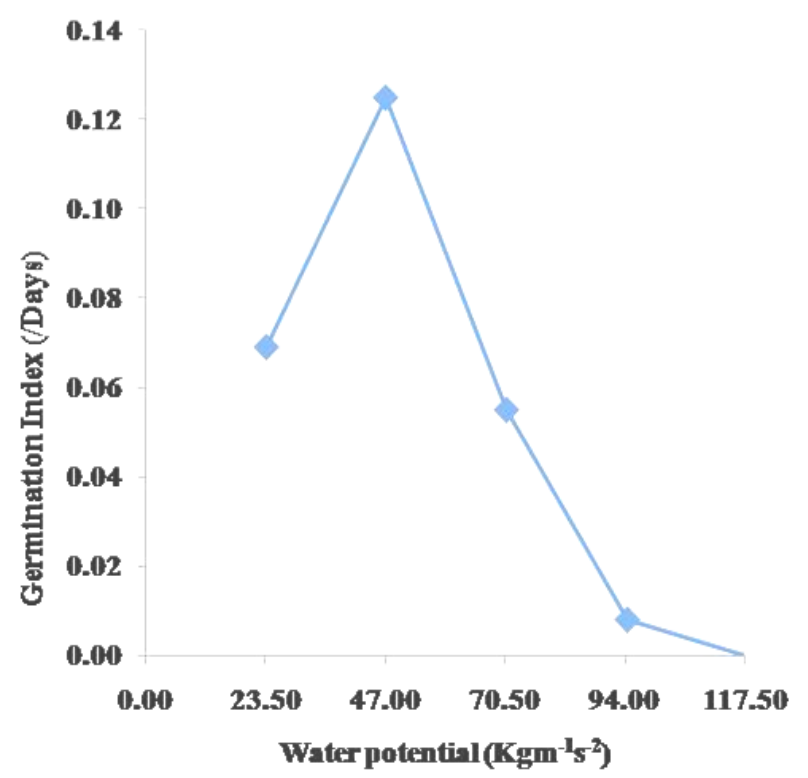

Fig. 12: Germination Index of the seeds of Abelmoschus esculentus at different water contents.

Germination index of okra was also showed the similar trend, after 7 days of germination (Figure 12). Seeds of okra showed differences in responses of seed germination under different moisture treatment. 
In a plant life cycle, seeds have the highest resistance to extreme environmental stresses, whereas seedlings are most susceptible to the environmental changes [13]. Therefore, successful establishment of a plant population is dependent on the adaptive aspects of seed germination and of early seedling growth in the particular environment [9]. Decreasing in the percentage of germination might be due to the enzymatic reactions that take place under the treatment conditions of seeds [12]. Growth of plant roots generally declines with decreasing room temperature in the 5-30 ${ }^{\circ} \mathrm{C}$ range, and reduced whole-plant growth and photosynthetic rate may be a result of reduced water and nutrient uptake [38]. Salinity and drought are the major factors which reduce seed germination and seedling growth [22, 29, 34, 37]. Water is a basic requirement for germination, the amount required is much less than that needed for sustain subsequent seedling and plant growth. If the growth of the seedlings is limited because of the soil moisture level, then the germination must be related to the soil water content required to sustain further growth. The ability of seeds to germinate at low soil water contents may lead to establishment failures in dry weather ensues, whereas seeds with a more exacting requirement for germination may establish more successfully [24, 25, 27, 40].

Water content was used in this experiment as a measure of availability of water for the seeds to germinate and emerge further. At low soil water contents, germination percentage of most of the species was highly reduced. Failure of living seed germination, or delay in germination under dry conditions may be due to insufficient moisture or hydration of the seeds. Most of the seeds germinated when transferred to moist filter papers. However, the fact that some seeds of most species managed to germinate at low soil water contents implies that this was not the case. Failure to germinate under moisture deficit could constitute an imposed and polymorphic dormancy mechanism which in many species is readily reversible when water supply is improved. Such a dormancy mechanism would have survival implications by preventing germination in soils not moist enough to support subsequent seedling growth [17]. As far as drought and most other environmental hazards are concerned, the seedling is likely to be the most vulnerable stage [23]. In some seeds, the internal characters might play a role in the seed germination. Seed germination was inhibited as a consequence of decline in the enzyme activity in maize seeds [20,21]. The responses of only one seed lot were examined, and different seed lots of the same genotype harvested under different environmental conditions may vary in their response to physiological stress during germination $[2,33]$.

The reduction in germination percentage may be attributed to lower capacity of water to diffuse into the seed coats at greater water stresses. In leguminous seeds, the water uptake of the seeds and plants decreases when external water potential is low [16]. Wheat plants had higher root growth under high water potential (less stress) conditions than under low water potential (high stress) conditions [26]. Aquaporins, the membrane proteins play a key role in plant water homeostasis in response to various environmental stresses [38]. Water potential gradient (reduced water availability) between the external environment and the seeds also inhibits the primary root emergence [11]. A seed must absorb a certain amount of water to germinate, the critical hydration level being species-specific $[14,15,18]$. Seed imbibition rates and the level of germination both decrease as soil water potential decreases $[4,5,8,18,41]$.

The seeds need higher amount of water uptake during the germination under the salt stress due to the accumulation of the soluble solutes around the seeds which increases the osmotic pressure. This causes excessive uptake of the ions which results in toxicity in the plant $[6,19]$. A water potential by temperature interaction was notable, with the minimum water potential for germination increasing at higher temperatures [1]. For, every species of seed, there is optimal soil water potential for germination, and at that water content, the maximum number of seeds will germinate and in less time than at any other water contents tested [32]. Flooding and drought are the extreme conditions where the germination of seeds is generally inhibited. Therefore different plant seeds show different germination characteristics based on the availability of water.

\section{CONCLUSION}

The seeds of Trichosanthes cucumerina, Momocardia charantia and Abelmoschus esculentus showed different range of water content tolerance for optimum germination. Optimum germination responses were expressed by Trichosanthes cucumerina and Momocardia charantia at $23.5 \mathrm{Kgm}^{-1} \mathrm{~s}^{-2}$ and Abelmoschus esculentus at $47.0 \mathrm{Kgm}^{-1} \mathrm{~s}^{-2}$.

\section{ACKNOWLEDGEMENT}

Authors acknowledge University of Jaffna for the Research grant 2015. The authors express their deep sense of gratitude and sincere thanks to P. T. J. Jashothan and A. Thananchayan, Department of Botany, University of Jaffna for their kind support and the timely help.

\section{Financial support and sponsorship: Nil.}

Conflict of Interests: There are no conflicts of interest.

\section{REFERENCES}

1. Alvardo V., Bradford KJ. A hydrothermal time model explains the cardinal temperatures for seed germination. Plant Cell and Environment. 2002; 25:1061-1069

2. Austin R.B. Effects of environment before harvesting on viability. In Viability of Seeds (Ed. by E. H. Roberts). Chapman and Hall, London. 1972;114-147.

3. Boundless. "Water and Solute Potential." Boundless Biology. Boundless, 08 Jan. 2016; Retrieved 13 Apr. 2016; from https://www.boundless.com/biology/textbooks/boundlessbiology-textbook/plant-form-and-physiology-30/transport-of-waterand-solutes-in-plants-183/water-and-solute-potential-696-11921/

4. Collis George N, Hector JB. Germination of seeds as influenced by matric potential and by area of contact between seed and soil water. Australian Journal of Agricultural Research.1966; 4:145-146 
5. Collis George N, Sands JE. The control of germination by moisture as a soil physical property. Australian Journal of Agricultural Research.1959; 10:628-636

6. Demir I, Mavi K. Effect of salt and osmotic Stresses on the germination of Pepper seeds of different maturation Stages, Braz Arch Biol Technol. 2008; 51 (5):897-902

7. Derek Bewley J, Black M, Halmer P. The encyclopedia of seeds. Science, technology and uses Cabi Series. 2006; 203.

8. Doneen L.D, Macgillivary J.M. Germination (emergence) of vegetable seed as affected by different soil moisture conditions. Plant Physiology, 1943;18:524-529.

9. Duan D, Li W, Liu X, Ouyang H, An P. Seed germination and seedling growth of Suaedasalsa under salt stress. Ann. Bot. Fennici. 2007; 44:161-169.

10. Egley GH, Duke SO. Physiology of weed seed dormancy and germination .In weed physiology. CRC press Boca Raton, FL. 1985; 27-64

11. Eneas Filho J, Oliveria Neto O.B, Prisco J.T., Gomes Filho E, Monterio C. Effects of salinity in vivo and in vitro on cotyledonary galactosidases from Vigna unguiculata (L.) Walp. during seed germination and seedling establishment. Revista Brasileira de Fisiologia Vegetal. 1995; 7(4):135-142.

12. Geressu K, Gezahagne M. Response of some lowland growing Sorghum (Sorghum bicolor L.Moench) accessions to salt stress during germination and seedling growth. Afr. J. Agric. Res. 2008; 3(1):044-048.

13. Gutterman Y. Seed germination in desert plants. Adaptations of desert organisms. Berlin: Springer-Verlag. 1993; 253.

14. Hadas A. Factors affecting seed germination under soil moisture stress. Israel Journal of Agricultural Research.1970; 20:3-14.

15. Hadas A, Russo D. Water uptake by seeds as affected by water stress, capillary conductivity, and seed-soil water contact I Experimental study. Agronomy Journal. 1974; 66: 643-647.

16. Hadas A, Russo D. Water uptake by seeds as affected by water stress, capillary conductivity, and seed-soil water contact II Analysis of experimental data. Agronomy Journal. 1976; 66, 647-652.

17. Hegarty HW. The physiology of seed hydration and dehydration, and the relation between water stress and control of germination: a review. Plant Cell and Environment. 1978; 1:101-119.

18. Hunter JR, Erickson AE. Relation of seed germination to soil moisture tension. Agronomy Journal. 1952; 44:107-109.

19. Jones RA. High salt tolerance potential in Lycopersicon species during germination. Euphytica. 1986; 35:575-582.

20. Kapilan R and Thiagarajah M. Effect of aging on the germination characteristics and enzyme activity of Sunflower seeds. International Journal of Research and Innovations in Earth Science, 2015; 2(6):147-150

21. Kapilan R. Accelerated aging declines the germination characteristics of the maize seeds, Scholars Academic Journal of Biosciences, 2015; 3(8):708-711.

22. Kaydan D, Yagmur M. Germination, seedling growth and relative water content of shoot in different seed sizes of triticale under osmotic stress of water and $\mathrm{NaCl}$. Afr J Biotechnol. 2008; 7(16): 2862-2868.

23. Matthews S. Seed in relation to ecology. Advances in Research and Technology of Seeds. 1976; 2:86-106.

24. Mc Ginnies WJ. Effects of moisture stress and temperature on germination of six range grasses. Agronomy Journal. 1960; 52:159 162.

25. Mc William JR, Phillip PJ. Effect of osmotic and matric potentials on the availability of water for seed germination. Australian Journal of Biological Sciences.1971; 24:423-4.

26. Mian MAR, Nafziger ED. Seed size effects on emergence, head number and grain yield of winter wheat. Journal of production Agriculture. 1992; 5:265-268.

27. Mott JJ. Factors affecting seed germination in three annual species from an arid region in Western Australia. Journal of Ecology. 1974; 62:699-709.
28. Newman S. Growing Plants from seed; Colorado State University Extension. 2009

29. Nirosha R, Thananthika S, Kapilan R. Optimization of salinity and temperature for the efficient seed germination of Momocardia charantia. International Journal of Advanced Research in Biological Sciences. 2015; 2(12):73-80

30. Raven L. 2009; Seed Dormancy in Commercial Vegetable and Flower Species; University of Kentucky.

31. R Development Core Team. 2011; A Language and Environment for Statistical Computing. R Foundation for Statistical Computing, Vienna, Austria.

32. Rizzadri MA et al., Effect of cardinal temperature and water potential on morning glory (Ipomoea triloba) seed germination. Planta Daninha, 2009; 27(1):13-21.

33. Roberts EH Temperature and seed germination. In: Plants and Temperature (Ed. by S. P. Long \& F. I. Woodward). Symposia of the Society of Experimental Biology, 1988; 42. Company of Biologists Ltd, Cambridge.

34. Shitole SM, Dhumal KN. Effect of water Stress by polyethylene glycol 6000 and sodium chloride on seed germination and seedling growth of Cassia angustifolia. International Journal of Pharmaceutical Sciences and Research. 2012; 3(2):528-53.

35. Taylorson R.B. Germination and seedling development of Canada thistle (Cirsium arvense). Weed Science . 1979; 27;146-151

36. Thananthika S, Nirosha R, Kapilan R. Determination of the influence of temperature and salinity on the germination of Abelmoschus esculentus seeds. International Journal of Recent Scientific Researches. 2015; 6 (10):7013-7017.

37. Thananthika S, Nirosha R., Kapilan R. Effect of temperature and salinity on the seed germination and seedling emergence of Trichosanthes cucumerina. International Journal of Advanced Research in Biological Sciences. 2015; 2(12):130-136.

38. Wan X, Zwiazek JJ, Lieffers VJ, Landhausser SM. Hydraulic conductance in aspen (Populus tremuloides) seedlings exposed to low root temperatures. Tree Physiology. 2011; 21:691-696.

39. Washa BW, Nyomora AMS, Lyaruu HV. Improving propagation Success of D.melanoxylon (African Blackwood) in Tanzania.I Characterization of mycorrhizal associated with Dalbergia melanoxylon (African Blackwood) in Tanzania, Tanzania Journal of Science. 2012; 38(1):43-53.

40. Watt LA. The effect of water potential on the germination behaviour of several warm season grass species, with special reference to cracking black clay soils. Journal of Soil Conservation New South Wales. 1974; 30:28-1

41. Williams J, Shaykewich CF. Influence of water matric potential and hydraulic conductivity on the germination of rape \{Brassica napus). Journal of Experimental Botany. 1971; 22:586-597.

\section{How to cite this article:}

Razeek N, Sittampalam T, Kapilan R Effect of water content on the germination characteristics of Trichosanthes cucumerina, Momocardia charantia and Abelmoschus esculentus seeds. J App Biol Biotech. 2016; 4 (05): 007-013. doi: 10.7324/JABB.2016.40502 